International Journal of

Supply Chain and Logistics

(IJSCL)

INFLUENCE OF STRATEGIC PROCUREMENTMANAGEMENT ON THE PERFORMANCE OF STAW

CORPORATIONS IN KENYA

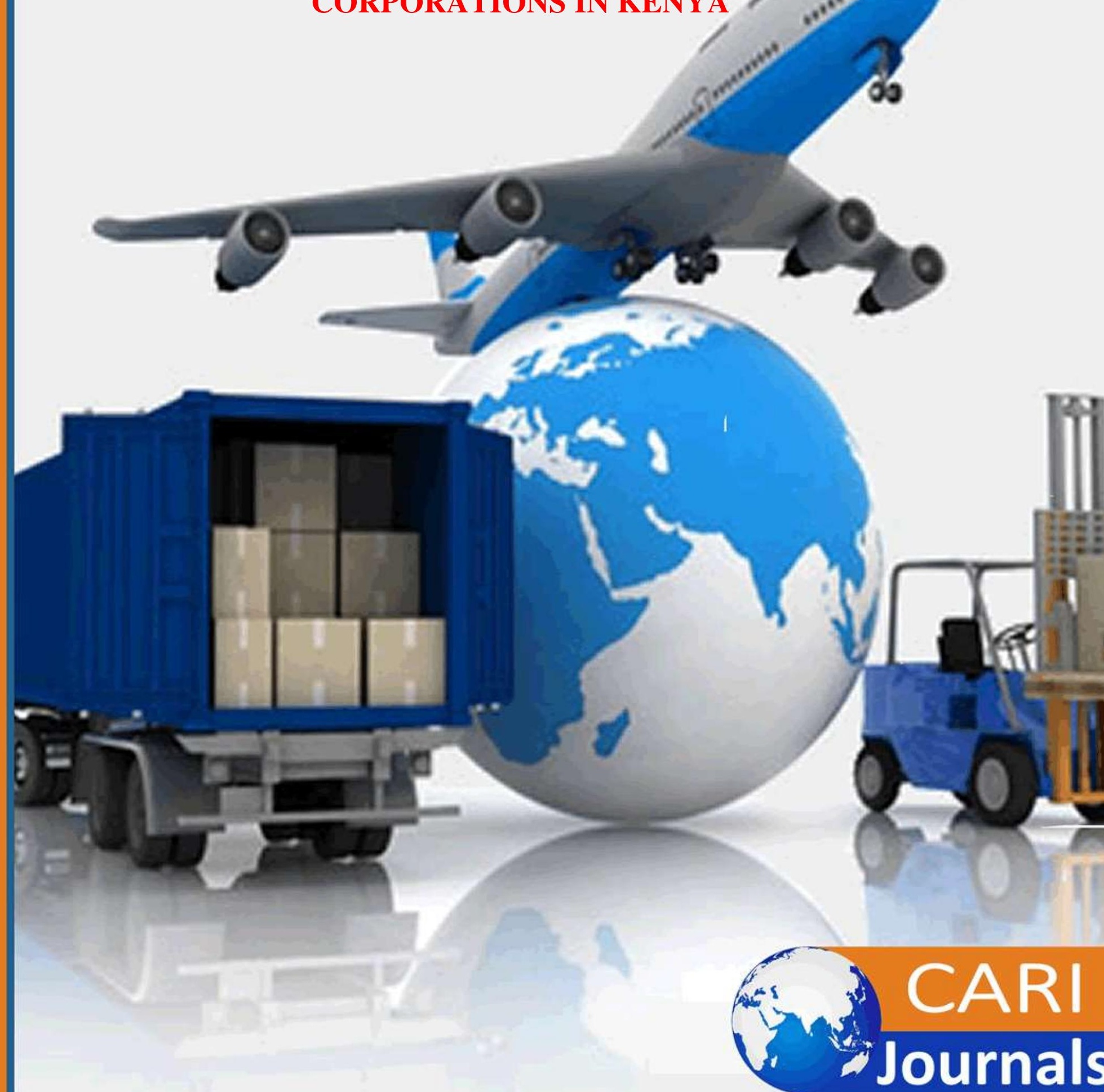




\title{
INFLUENCE OF STRATEGIC PROCUREMENT MANAGEMENT ON THE PERFORMANCE OF STATE CORPORATIONS IN KENYA
}

\author{
1* Michael Nyangate Basweti, \\ ${ }^{1 *}$ Post Graduate Student, Department of Procurement and Logistics \\ Jomo Kenyatta University of Agriculture and Technology \\ *Author's E-mail: MBasweti@kplc.co.ke \\ ${ }^{2}$ Dr. John Achuora \\ Lecturer, Department of Procurement and Logistics, \\ Jomo Kenyatta University of Agriculture and Technology
}

\begin{abstract}
Purpose: The purpose of the study was to establish whether strategic procurement management has contributed to the performance of state corporations in Kenya.

Methodology: The study employed a descriptive research design; the researcher preferred this method because it allowed an in-depth study of the subject. The target population was all the 187 heads of procurement of the state corporations in Kenya. From the four strata, a sample of 127 was selected using simple random sampling. Semi-structured questionnaires were administered to collect qualitative and quantitative data. Once collected, data was analyzed using descriptive and inferential statistics. Quantitative data was analyzed using multiple regression analysis. The qualitative data generated was analyzed by use of Statistical Package of Social Sciences (SPSS) version 21.

Results: In regard to inventory management system, the regression coefficients of the study show that it has a significant influence of 0.561 on performance of state corporations. Second in regard to strategic sourcing, the regression coefficients of the study show that it has a significant influence of 0.198 on performance of state corporations. With regard to supply base leveraging, the regression coefficients of the study show that it has a significant influence of 0.112 on performance of state corporations. Lastly, in regard to the fourth objective, the regression coefficients of the study show that it has a significant influence of 0.019 on performance of state corporations.
\end{abstract}

Conclusion: Based on the findings, the study concluded that supply base leveraging, inventory management system, e-procurement and strategic sourcing have a positive relationship with performance of the state corporations.

Policy Recommendation: The study recommended that public institutions should embrace strategic procurement management so as to improve performance and further researches should to be carried out in other public institutions to find out if the same results can be obtained.

Keywords: strategic procurement management, performance, state corporations 


\subsection{INTRODUCTION}

\subsection{Background of the Study}

The organizations whether for profit or non-profit, private or public have found it necessary in recent years to engage in strategic procurement management in order to achieve their corporate goals. The environments in which they operate have become not only increasingly uncertain but also more tightly interconnected. This requires a threefold response from these organizations. They are required to think strategically as never before, need to translate their insight into effective strategies to cope with their changed circumstances and lastly, develop rationales necessary to lay the groundwork for adopting and implementing strategies in this ever-changing environment (Andersen, 2010).

Strategic procurement management is a unifying theme that gives coherence and direction to the actions and decisions of an organization. It guides an organization to superior performance by helping establish competitive advantage. It acts as a vehicle for communication and coordination within the organization. The goal of strategic management therefore is to build and maintain sustainable competitive advantage and create stakeholders wealth. Strategic procurement management process includes formulation, implementation, evaluation and control (Chandler, 2012).

\subsubsection{Global Perspective of the Study}

In today's competitive business environment, many companies are trying to find new ways to achieve a competitive advantage. Many changes have happened to the viewpoints of companies about the function of purchasing. Purchasing has commenced to play a more significant role in the strategy of the firm during the past few years. The recent evolvement of purchasing expanded from "buying" to "procurement" and then to "supply management" has found a similar growing importance as well as supply chain management (Qiu, 2012). The strategic role of purchasing as an important contributor to the strategic success of the company is receiving enhanced attention. The movement away from the philosophies of mass production has brought new ways to the traditionally operational task of purchasing and this has created the concept of purchasing as a part of the strategic function of supply chain management which should be aligned to the overall corporate strategy (Strickland, 2009).

\subsubsection{Regional Perspective of the Study}

Many of the developing nations were colonized and when they became independent they inherited governance structures from their colonial masters. The post-colonial public sector of these nations therefore, delivered services to their people based on the skills derived from their masters and more importantly; this was done under mono-party political dictatorship. The challenges of such a set up are obvious: skewed distribution of government resources, bloated civil service and inherent misappropriation of money (Taiwo \& Idumo, 2010).

\subsubsection{Local Perspective of the Study}

According to Nderu (2013) the Kenya government decentralized its services in order to achieve its development agenda for its citizens. Decentralization in this case can be defined as a process in which public functions are transferred to a subordinate or semi-autonomous government organizations or the private sector from the central government. In this case the power and responsibility for such entities (organizations) to carry out public functions are bestowed upon them. The transfer of services can be in different forms namely de- 
concentration, delegation, devolution or privatization and comprises of fiscal, administrative, economic and functions (Nzuve \& Musyoka, 2012).

\subsection{Problem Statement}

The procurement area is the largest single category of spend, ranging from $50 \%$ to $85 \%$ of revenue. The interest in this topic has emanated from many drivers, including trends such as rampant delay in delivery, low quality products, dissatisfied customers and the dwindling triple bottom-line (CBK, 2013). It is estimated that $18.42 \%$ of the world's Gross Domestic Product (GDP) is spent through public procurement (Johnson \& Scholes, 2015). It is further estimated that public procurement accounts for 9\%-13\% of the GDP of the economies of developing countries like Kenya. This therefore means that every effort should be made to erect safeguards to check against massive losses in public procurement (PPOA, 2010).

According to statistics from the World Bank (2013) there was a 42.7\% drop in profits to Sh629 million from Sh1.64 billion a year earlier at Geothermal Development Company (GDC) and the public sector in general recorded a decline in performance. A report by CCG (2010) indicates that in some state corporations such as Kenya Electricity Generating Company (KenGen), the total operating expenditure increased by $2 \%$ compared to similar period in 2011. According to a report by KIPPRA (2010) state corporations, therefore, need to adopt strategic procurement management that will entail application of innovative inventory management systems and strategic sourcing among others that will bring about competitive advantages in terms of broader market share, profitability and customer satisfaction.

Several studies have been done, at the global level; Knudsen (2009) examined the relationship between a firm's procurement strategy and its performance. They surveyed 82 Swedish business firms and reported a link between procurement strategy and performance. They noted that procurement strategy enables a firm to strengthen its competitive position, and facilitates integration and coordination of members' behavior.

Locally, Wangari (2013) carried out a study on the influence of competitive procurement strategies on the performance of hair salons in Nairobi. The study concluded that variables of differentiation strategy in the industry indicate existence of a relationship between strategy and performance, Nyariki (2013) did a study on strategic procurement management practices as a competitive tool in enhancing the performance of small and medium enterprises in Kenya. She found that strategic procurement management has a positive relationship with competitive advantage of the organizations. However, none of these studies assessed the influence of strategic procurement management on the performance of state corporations in Kenya. Informed by this knowledge gap, this study sought to establish the influence of strategic procurement management on the performance of state corporations in Kenya.

\subsection{Objectives of the Study}

1. To assess the influence of supply base leveraging on the performance of state corporations in Kenya

2. To establish the influence of inventory management system on the performance of state corporations in Kenya.

3. To determine the influence of e-procurement on the performance of state corporations in Kenya.

4. To evaluate the influence of strategic sourcing on the performance of state corporations in Kenya. 


\subsection{LITERATURE REVIEW}

\subsection{Empirical Review}

\subsubsection{Supply Base Leveraging}

One of the earliest papers in supply base leveraging is attributed to Hansen, SchaumburgMuller and Pottenger (2012) where they opine that competing in the 21st century will require firms to rely increasingly on their suppliers. For a firm to deliver maximum value to its customers, it must receive maximum value from all its suppliers in the supply chain. Commercial firms are increasingly finding out that, working in isolation will not lead to lowest costs, best quality, or shortest cycle times in their firms if their suppliers do not get involved. Intel, for instance, concluded that it could not improve the quality of its products if it did not improve the quality of its suppliers. Sun concluded that to be more responsive to its customers its suppliers needed to be more responsive. There is therefore need for supplier optimization, strategic alliances and supplier development.

\subsubsection{Inventory Management System}

Ming-Ling and Shaw (2012) analyzed the warehouse and inventory management system in Shell Petroleum Development Company (SPDC) in Nigeria and demonstrated the utility of ICT through vendor managed inventory (VMI) as a veritable value-added tool in inventory management practice. Robert (2010) also tried to justify the use of modified Just in Time (JIT) logistic-based approach to managing inventory of perishable products. Sari (2012) used statistical process monitoring tools with inventory levels and stock-outs as key metrics in achieving proactive inventory policy intervention in the context of cooperative supply chains. Their results showed the possibility of detecting out-of-control supplier signals beforehand and significantly reducing stock-outs through dynamic adjustments of inventory levels.

\subsubsection{E-Procurement}

According to Mose (2012), private and public sector organizations have been utilizing information technology (IT) systems to streamline and automate their purchasing and other processes over the past years. E-sourcing is not new; Thai (2011) there have been many attempts to automate the process of procurement for the buyer using electronic procurement systems (EPS), workflow systems and links with suppliers through electronic data interchange (EDI). E-sourcing refers to the electronic integration and management of all procurement activities including purchase, request, authorization, ordering, delivery and payment between a purchaser and a supplier (Lysons, 2013).

\subsubsection{Strategic Sourcing}

According to (Kotabe et al., 2010), outsourcing has been considered as a field of investigation in many different fields, spanning from the management of information systems to the international business. Despite the heterogeneity of its definition, scholars agree that the decision to outsource concerns a reliance of firms on external sources of inputs, services, processes, or other value-adding activities, balancing the span of activities that a firm performs internally versus those that are acquired from outside.

\subsubsection{Performance of State Corporations}

According to Lysons (2013) there are a lot of arguments about performance measurement, and it has no consistent opinion until now. The most notable perceived benefit from participating in the strategic procurement management is lower unit cost of procurement. 
There are more contributions when firms delivered strategic procurement in supply chain. Rotich (2011) opined that short and reliable order cycles, and the ability to fill entire orders are critical elements to customer service. And they measured business performance with senior management's perceptions of a firm's performance in comparison to that of major competitors.

\subsection{Theoretical Review}

\subsubsection{Partnership Theory}

This theory was developed in the 17th century by philosopher Hobbes who argued that in supply chain, the common model through which theorists study the relationship between supplier and buyer is known as the partnership theory. In its basic nature, the partnership model depicts the buyer and supplier as partners with a common interest which is customer satisfaction (Kotabe et al., 2010). Partnership is a business relationship based on mutual trust openness, shared risks and rewards that enables an organization gain competitive advantage leading in the company achieving a performance that's far much greater than the firm would have achieved when operating as single entities. This model requires efficient information exchange between the buyer and supplier which is a critical element of any partnership (Humphreys, McIvor \& Cadden, 2010).

The theory further states that any partnership is always based on value and present for each other. The solid and long term relationship simply implies continuous improvement of the organization performance. Suppliers must provide better services that are of high quality than his competition at a price reasonable and still achieve goals to remain in business. Partnership model according to Gabbard (2014), increases company efficiency through way of cooperative; both parties obtain cost reduction which leads to price reduction and therefore increasing the market share profit margin as well. This leads to a company gaining a competitive edge and efficiency.

The character which forms the perceived attributes of partnership include the following; high frequency of both formal and informal communication, cooperative attitude, trusting relations are built, problem solving that is win negotiation style, long term business agreement, open sharing of information and there is always vendor certification and defect prevention approach. Motivation factors, environment of operation, strength of operation and duration of operation vary in different partnership formed. However there is never an ideal relationship that is recommended (Cummings \& Qiao, 2013).

The partnership theory has three elements which are drivers, facilitators' and used components. The drivers each party must have a driver strong enough to provide them with realistic expectation of significance benefit through strengthening of the relationship. Facilitators on the other have included corporate compatibility, mutuality, managerial philosophy and techniques and symmetry. The final element is the components which are the factors than can be controlled in a partnership by the management. They include supplier optimization, strategic alliances, communications, risk/reward sharing, trust and commitment, supplier development, scope and financial investment (Cox, 2013). 


\subsection{Conceptual Framework}

\section{Supply Base Leveraging}

- Supplier Optimization

- Strategic Alliances

- Supplier Development

\section{Inventory Management System}

- Just in Time

- Vendor Managed Inventory

- Economic Order Quantity

\section{E-Procurement \\ - E- Sourcing \\ - E- Informing \\ - E- Payments}

\section{Strategic Sourcing}

- Outsourcing

- Green Procurement

- Multi Sourcing

\section{Independent Variables}

\section{Performance of State Corporations}

- Profitability

- Market Share

- Customer Satisfaction

\section{Figure 1: Conceptual Framework}

Dependent Variable

\subsection{RESEARCH METHODOLOGY}

The study employed a descriptive research design; the researcher preferred this method because it allowed an in-depth study of the subject. The target population was all the 187 heads of procurement of the state corporations in Kenya. From the four strata, a sample of 127 was selected using simple random sampling. Semi-structured questionnaires were administered to collect qualitative and quantitative data. Once collected, data was analyzed using descriptive and inferential statistics. Quantitative data was analyzed using multiple regression analysis. The qualitative data generated was analyzed by use of Statistical Package of Social Sciences (SPSS) version 21. 


\subsection{RESULTS AND DISCUSSIONS}

\subsection{Response Rate}

A sample of 127 respondents were interviewed using questionnaires that allowed the researcher to drop the questionnaire to the respondents and then collect them at a later date when they had filled the questionnaires. A total of 127 questionnares were distributed to employees. Out of the population covered, 117 were responsive respresenting a response rate of $92.13 \%$. This was above the $50 \%$ which is considered adequate in descriptive statistics according to (Mugenda \& Mugenda, 2014).

Table 1: Response Rate of Respondents

\begin{tabular}{lll}
\hline Response & Frequency & Percentage \\
\hline Actual Response & 117 & $92.13 \%$ \\
Non-Response & 10 & $7.87 \%$ \\
Total & 127 & $100 \%$ \\
\hline
\end{tabular}

\subsection{Descriptive Statistics}

\subsubsection{Supply Base Leveraging}

The first objective of the study was to assess the influence of supply base leveraging on the performance of state corporations in Kenya. The respondents were asked to indicate to what extent supply base leveraging influenced performance of performance of state corporations in Kenya. Results indicated that majority of the respondents $50 \%$ said it was effective, $40 \%$ said that it was very effective, $5 \%$ said it was ineffective, while $5 \%$ also said it was somehow effective.

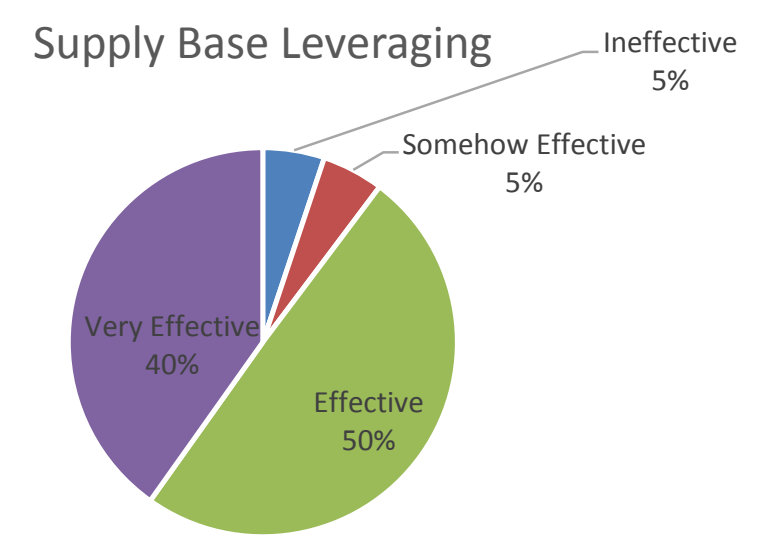

\section{Figure 2: Supply Base Leveraging}

The respondents were also asked to comment on statements regarding the influence of supply base leveraging on the performance of state corporations in Kenya. 
The responses were rated on a likert scale and the results presented in Table 2 below. It was rated on a 5 point likert scale ranging from; $1=$ strongly disagree to $5=$ strongly agree. The scores of 'strongly disagree' and 'disagree' have been taken to represent a statement not agreed upon, equivalent to mean score of 0 to 2.5. The score of 'neutral' has been taken to represent a statement agreed upon, equivalent to a mean score of 2.6 to 3.4. The score of 'agree' and 'strongly agree' have been taken to represent a statement highly agreed upon equivalent to a mean score of 3.5 to 5 .

Results indicated that majority of the respondents $77 \%$ agreed on the statement that supplier optimization plays a significant role in profitability improvement. Further results indicated that $82.1 \%$ of the respondents agreed that strategic alliances play a significant role in profitability improvement. $81.2 \%$ of the respondents further agreed that supplier development plays a significant role in profitability improvement.

$79.5 \%$ of the respondents expressed agreement on the statement that supplier optimization plays a significant role in expanding market share. Results indicated that majority of the respondents $78.7 \%$ agreed on the statement that strategic alliances play a significant role in expanding market share. Results also indicated that majority of the respondents $80.3 \%$ agreed on the statement that Supplier development plays a significant role in expanding market share.

Results indicated that majority of the respondents $81.2 \%$ agreed on the statement that supplier optimization play a significant role in attaining higher customer satisfaction. Results indicated that majority of the respondents $77.8 \%$ agreed on the statement that strategic alliances play a significant role in attaining higher customer satisfaction. Also, results indicated that supplier development plays a significant role in attaining higher customer satisfaction as shown by $82.1 \%$ of the respondents agreeing on the statement.

The average mean of all the statements was 4.01 indicating that majority of the respondents agreed with the statement that supply base leveraging had an influence on the performance of state corporations in Kenya. However the variations in the responses were varied as shown by a standard deviation of 1.147. The findings agree with Odundo (2012) that practicing supply base leveraging when sourcing can be smart but if not done well can prove to be expensive and time consuming. 
Table 2: Supply Base Leveraging

\begin{tabular}{|c|c|c|c|c|c|c|c|}
\hline Statements & $\begin{array}{l}\text { Stron } \\
\text { gly } \\
\text { Disag } \\
\text { ree }\end{array}$ & $\begin{array}{c}\text { Disag } \\
\text { ree }\end{array}$ & $\begin{array}{c}\text { Neutra } \\
1 \\
\end{array}$ & Agree & $\begin{array}{c}\text { Strongl } \\
\text { y } \\
\text { Agree }\end{array}$ & $\begin{array}{c}\text { Mea } \\
\mathbf{n} \\
\end{array}$ & $\begin{array}{l}\text { Std. } \\
\text { Devi } \\
\text { ation }\end{array}$ \\
\hline $\begin{array}{l}\text { Supplier optimization plays } \\
\text { a significant role in } \\
\text { profitability improvement }\end{array}$ & $6.80 \%$ & $6.00 \%$ & $10.30 \%$ & $40.20 \%$ & $36.80 \%$ & 3.94 & 1.154 \\
\hline $\begin{array}{l}\text { Strategic alliances play a } \\
\text { significant role in } \\
\text { profitability improvement }\end{array}$ & $6.80 \%$ & $6.00 \%$ & $5.10 \%$ & $34.20 \%$ & $47.90 \%$ & 4.1 & 1.177 \\
\hline $\begin{array}{l}\text { Supplier development plays } \\
\text { a significant role in } \\
\text { profitability improvement }\end{array}$ & $6.00 \%$ & $6.00 \%$ & $6.80 \%$ & $35.90 \%$ & $45.30 \%$ & 4.09 & 1.141 \\
\hline $\begin{array}{l}\text { Supplier optimization play a } \\
\text { significant role in expanding } \\
\text { market share }\end{array}$ & $8.50 \%$ & $6.00 \%$ & $6.00 \%$ & $41.90 \%$ & $37.60 \%$ & 3.94 & 1.206 \\
\hline $\begin{array}{l}\text { Strategic alliances play a } \\
\text { significant role in expanding } \\
\text { market share }\end{array}$ & $3.40 \%$ & $7.70 \%$ & $10.30 \%$ & $38.50 \%$ & $40.20 \%$ & 4.04 & 1.062 \\
\hline $\begin{array}{l}\text { Supplier development plays } \\
\text { a significant role in } \\
\text { expanding market share }\end{array}$ & $7.70 \%$ & $6.00 \%$ & $6.00 \%$ & $35.00 \%$ & $45.30 \%$ & 4.04 & 1.206 \\
\hline $\begin{array}{l}\text { Supplier optimization play a } \\
\text { significant role in attaining } \\
\text { higher customer satisfaction }\end{array}$ & $6.00 \%$ & $6.80 \%$ & $6.00 \%$ & $44.40 \%$ & $36.80 \%$ & 3.99 & 1.118 \\
\hline $\begin{array}{l}\text { Strategic alliances play a } \\
\text { significant role in attaining } \\
\text { higher customer satisfaction }\end{array}$ & $\begin{array}{c}10.30 \\
\%\end{array}$ & $6.80 \%$ & $5.10 \%$ & $37.60 \%$ & $40.20 \%$ & 3.91 & 1.286 \\
\hline $\begin{array}{l}\text { Supplier development plays } \\
\text { a significant role in attaining } \\
\text { higher customer satisfaction }\end{array}$ & $1.70 \%$ & $9.40 \%$ & $6.80 \%$ & $46.20 \%$ & $35.90 \%$ & 4.05 & 0.981 \\
\hline Average & & & & & & 4.01 & 1.147 \\
\hline
\end{tabular}




\subsubsection{Inventory Management System}

The second objective of the study was to establish the influence of inventory management system on the performance of state corporations in Kenya. The respondents were asked to indicate to what extent inventory management system affected performance of state corporations in Kenya. Results indicated that majority of the respondents $46 \%$ agreed that it was very effective, $39 \%$ said that it was effective, $9 \%$ said it was ineffective, while somehow effective was at $6 \%$.

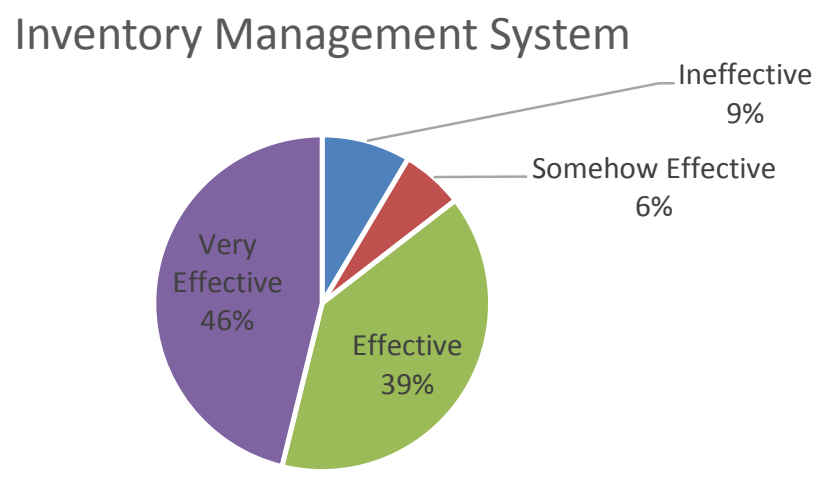

\section{Figure 3: Inventory Management System}

The respondents were also asked to comment on statements regarding effect of inventory management systems on performance of state corporations in Kenya. Results indicated that majority of the respondents $83 \%$ agreed on statement that just in time sourcing plays a significant role in profitability improvement. Further results indicated that $77 \%$ of the respondents were in agreement that vendor managed inventory system plays a significant role in profitability improvement. $74.4 \%$ of the respondents agreed that economic order quantity system plays a significant role in profitability improvement.

$74.4 \%$ of the respondents expressed agreement on the statement that just in time sourcing plays a significant role in expanding market share. Results indicated that majority of the respondents $81.2 \%$ agreed on the statement that vendor managed inventory system plays a significant role in expanding market share. Results indicated that majority of the respondents $77.8 \%$ agreed on the statement that economic order quantity system plays a significant role in expanding market share.

Results indicated that majority of the respondents $71.8 \%$ agreed on the statement that just in time sourcing plays a significant role in attaining higher customer satisfaction. Results indicated that majority of the respondents $53 \%$ agreed on the statement that vendor managed inventory system plays a significant role in attaining higher customer satisfaction. Results indicated that majority of the respondents $67.5 \%$ agreed on the statement that economic order quantity system plays a significant role in attaining higher customer satisfaction.

The average mean of all the statements was 3.85 indicating that majority of the respondents agreed that inventory management systems had an influence on performance of state corporations in Kenya. However the variations in the responses were varied as shown by a standard deviation of 1.206. These findings agree with Nyariki (2013) that organizations must 
look toward their inventory management system for improvements. The opportunities for cost savings can be enormous as the impact on margins and bottom line is considerable.

Table 3: Inventory Management System

\begin{tabular}{|c|c|c|c|c|c|c|c|}
\hline Statements & $\begin{array}{c}\text { Strongl } \\
\mathbf{y} \\
\text { Disagr } \\
\text { ee } \\
\end{array}$ & $\begin{array}{c}\text { Disagr } \\
\text { ee }\end{array}$ & Neutral & Agree & $\begin{array}{c}\text { Strong } \\
\text { ly } \\
\text { Agree } \\
\end{array}$ & $\begin{array}{c}\text { Mea } \\
\mathbf{n}\end{array}$ & $\begin{array}{l}\text { Std. } \\
\text { Devi } \\
\text { ation }\end{array}$ \\
\hline $\begin{array}{l}\text { Just in time sourcing } \\
\text { plays a significant role in } \\
\text { profitability } \\
\text { improvement }\end{array}$ & $6.00 \%$ & $5.10 \%$ & $6.00 \%$ & $46.20 \%$ & $36.80 \%$ & 4.03 & 1.086 \\
\hline $\begin{array}{l}\text { Vendor managed } \\
\text { inventory system plays a } \\
\text { significant role in } \\
\text { profitability } \\
\text { improvement }\end{array}$ & $7.70 \%$ & $7.70 \%$ & $7.70 \%$ & $40.20 \%$ & $36.80 \%$ & 3.91 & 1.203 \\
\hline \begin{tabular}{lcr} 
Economic & \multicolumn{3}{c}{ order quantity } \\
system plays a \\
significant role in \\
profitability & & \\
improvement & &
\end{tabular} & $11.10 \%$ & $3.40 \%$ & $11.10 \%$ & $38.50 \%$ & $35.90 \%$ & 3.85 & 1.264 \\
\hline $\begin{array}{l}\text { Just in time sourcing } \\
\text { plays a significant role in } \\
\text { expanding market share }\end{array}$ & $7.70 \%$ & $9.40 \%$ & $8.50 \%$ & $30.80 \%$ & $43.60 \%$ & 3.93 & 1.264 \\
\hline $\begin{array}{l}\text { Vendor managed } \\
\text { inventory system plays a } \\
\text { significant role in } \\
\text { expanding market share }\end{array}$ & $10.30 \%$ & $1.70 \%$ & $6.80 \%$ & $48.70 \%$ & $32.50 \%$ & 3.91 & 1.179 \\
\hline $\begin{array}{l}\text { Economic order quantity } \\
\text { system plays a } \\
\text { significant role in } \\
\text { expanding market share }\end{array}$ & $6.00 \%$ & $6.80 \%$ & $9.40 \%$ & $43.60 \%$ & $34.20 \%$ & 3.93 & 1.12 \\
\hline $\begin{array}{l}\text { Just in time sourcing } \\
\text { plays a significant role in } \\
\text { attaining higher } \\
\text { customer satisfaction }\end{array}$ & $5.10 \%$ & $0.00 \%$ & $23.10 \%$ & $30.80 \%$ & $41.00 \%$ & 4.03 & 1.054 \\
\hline $\begin{array}{l}\text { Vendor managed } \\
\text { inventory system plays a } \\
\text { significant role in } \\
\text { attaining higher } \\
\text { customer satisfaction }\end{array}$ & $17.10 \%$ & $6.80 \%$ & $23.10 \%$ & $33.30 \%$ & $19.70 \%$ & 3.32 & 1.337 \\
\hline Economic order quantity & $11.10 \%$ & $9.40 \%$ & $12.00 \%$ & $29.90 \%$ & $37.60 \%$ & 3.74 & 1.348 \\
\hline
\end{tabular}




$\begin{array}{lc}\text { system plays a } & \text { a } \\ \text { significant role in } \\ \text { attaining } & \text { higher } \\ \text { customer satisfaction }\end{array}$

Average

\subsubsection{E-procurement}

There was also need to determine the influence of e-procurement on the performance of state corporations in Kenya. The respondents were asked to comment on the influence of eprocurement on performance of state corporations in Kenya. Results indicated that majority of the respondents $45 \%$ agreed that it was very effective, $41 \%$ said that it was effective, while ineffective was at $8 \%$ and somehow effective tied at $6 \%$.

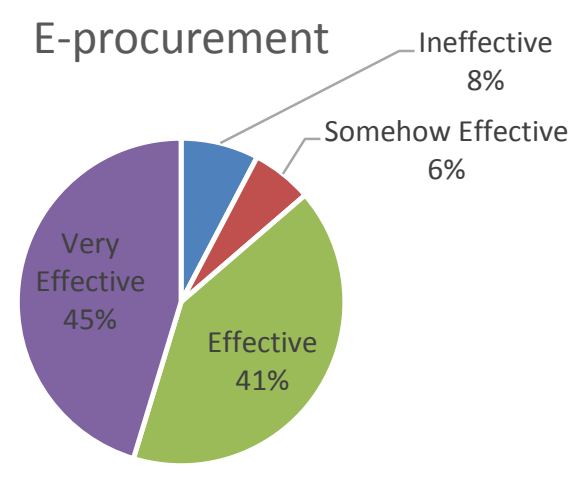

\section{Figure 4: E-procurement}

The respondents were also asked to comment on statements regarding effect of eprocurement on the performance of state corporations in Kenya. Results indicated that $77 \%$ agreed on the statement that e-sourcing plays a significant role in profitability improvement. Majority of the respondents $85.5 \%$ agreed on the statement that e-informing plays a significant role in profitability improvement. Further results indicated that $51.3 \%$ of the respondents were in agreement with the statement that e-payments play a significant role in profitability improvement.

$80.4 \%$ of the respondents agreed that e-sourcing plays a significant role in expanding market share. $75.3 \%$ of the respondents expressed agreement on the statement that e-informing plays a significant role in expanding market share. Results indicated that majority of the respondents $79.5 \%$ agreed on the statement that e-payments play a significant role in expanding market share.

Results indicated that majority of the respondents $79.5 \%$ agreed on the statement that esourcing plays a significant role in attaining higher customer satisfaction. Results indicated that majority of the respondents $71 \%$ agreed on the statement that e-informing plays a significant role in attaining higher customer satisfaction. Results also indicated that majority of the respondents $79.5 \%$ agreed on the statement that e-payments play a significant role in attaining higher customer satisfaction. 
The average mean of all the statements was 3.92 indicating that majority of the respondents agreed on e-procurement having an effect on the performance of state corporations in Kenya. However the variations in the responses were varied as shown by a standard deviation of 1.157. These findings imply that through information technology adoption, companies can improve competitive positioning, gain entry to new dynamic, technology driven markets, supplement critical skills and share the risk (Noor, Guyo \& Amuhaya, 2013).

Table 4: E-Procurement

\begin{tabular}{|c|c|c|c|c|c|c|c|}
\hline Statements & $\begin{array}{l}\text { Stron } \\
\text { gly } \\
\text { Disag } \\
\text { ree }\end{array}$ & $\begin{array}{c}\text { Disagr } \\
\text { ee }\end{array}$ & $\begin{array}{c}\text { Neutra } \\
1\end{array}$ & Agree & $\begin{array}{l}\text { Strong } \\
\text { ly } \\
\text { Agree } \\
\end{array}$ & $\begin{array}{c}\text { Mea } \\
\mathbf{n}\end{array}$ & $\begin{array}{l}\text { Std. } \\
\text { Deviat } \\
\text { ion }\end{array}$ \\
\hline $\begin{array}{l}\text { E-sourcing plays a } \\
\text { significant role in } \\
\text { profitability improvement }\end{array}$ & $9.40 \%$ & $8.50 \%$ & $5.10 \%$ & $46.20 \%$ & $30.80 \%$ & 3.8 & 1.233 \\
\hline $\begin{array}{l}\text { E-informing plays a } \\
\text { significant role in } \\
\text { profitability improvement }\end{array}$ & $2.60 \%$ & $5.10 \%$ & $6.80 \%$ & $37.60 \%$ & $47.90 \%$ & 4.23 & 0.968 \\
\hline $\begin{array}{l}\text { E-payments play a } \\
\text { significant role in } \\
\text { profitability improvement }\end{array}$ & $8.50 \%$ & $17.90 \%$ & $22.20 \%$ & $28.20 \%$ & $23.10 \%$ & 3.39 & 1.259 \\
\hline $\begin{array}{l}\text { E-sourcing plays a } \\
\text { significant role in } \\
\text { expanding market share }\end{array}$ & $6.00 \%$ & $6.80 \%$ & $6.80 \%$ & $41.90 \%$ & $38.50 \%$ & 4 & 1.13 \\
\hline $\begin{array}{l}\text { E-informing plays a } \\
\text { significant role in } \\
\text { expanding market share }\end{array}$ & $6.80 \%$ & $11.10 \%$ & $6.80 \%$ & $38.50 \%$ & $36.80 \%$ & 3.87 & 1.221 \\
\hline $\begin{array}{l}\text { E-payments play a } \\
\text { significant role in } \\
\text { expanding market share }\end{array}$ & $6.80 \%$ & $6.80 \%$ & $6.80 \%$ & $34.20 \%$ & $45.30 \%$ & 4.04 & 1.192 \\
\hline $\begin{array}{l}\text { E-sourcing plays a } \\
\text { significant role in } \\
\text { attaining higher customer } \\
\text { satisfaction }\end{array}$ & $8.50 \%$ & $4.30 \%$ & $7.70 \%$ & $41.90 \%$ & $37.60 \%$ & 3.96 & 1.185 \\
\hline $\begin{array}{l}\text { E-informing plays a } \\
\text { significant role in } \\
\text { attaining higher customer } \\
\text { satisfaction }\end{array}$ & $2.60 \%$ & $0.90 \%$ & $25.60 \%$ & $30.80 \%$ & $40.20 \%$ & 4.05 & 0.964 \\
\hline $\begin{array}{l}\text { E-payments play a } \\
\text { significant role in } \\
\text { attaining higher customer } \\
\text { satisfaction }\end{array}$ & $9.40 \%$ & $6.80 \%$ & $4.30 \%$ & $36.80 \%$ & $42.70 \%$ & 3.97 & 1.266 \\
\hline Average & & & & & & 3.92 & 1.157 \\
\hline
\end{tabular}




\subsubsection{Strategic Sourcing}

There was also need to evaluate the influence of strategic sourcing on the performance of state corporations in Kenya. The respondents were also asked to comment on statements regarding strategic sourcing on performance of state corporations in Kenya. Results showed that $49 \%$ of respondents indicated it was very effective, effective were at $38 \%$, somehow effective was $8 \%$, while ineffective was at $5 \%$.

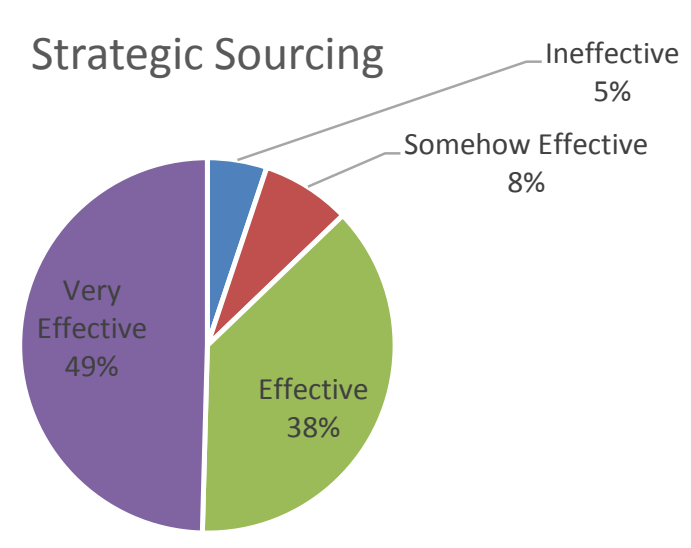

\section{Figure 5: Strategic Sourcing}

Results indicated that majority of the respondents $83.7 \%$ agreed on the statement that outsourcing plays a significant role in profitability improvement. A further $54.8 \%$ of the respondents agreed that green procurement plays a significant role in profitability improvement. $50.5 \%$ of the respondents expressed agreement on the statement that multi sourcing plays a significant role in profitability improvement.

Results indicated that majority of the respondents $86.3 \%$ agreed on the statement that outsourcing plays a significant role in expanding market share. Results indicated that majority of the respondents $87.1 \%$ agreed on the statement that green procurement plays a significant role in expanding market share. $85.4 \%$ of the respondents expressed agreement on the statement that multi sourcing plays a significant role in expanding market share.

Results indicated that majority of the respondents $82 \%$ agreed on the statement that outsourcing plays a significant role in attaining higher customer satisfaction. Results indicated that majority of the respondents $80.4 \%$ agreed on the statement that green procurement plays a significant role in attaining higher customer satisfaction. $86.3 \%$ of the respondents also agreed with the statement that multi sourcing plays a significant role in attaining higher customer satisfaction.

The average mean of all the statements was 3.98 indicating that majority of the respondents agreed strategic sourcing had an influence on the performance of state corporations in Kenya. However the variations in the responses were varied as shown by a standard deviation of 1.085. The results imply that an organization benefits greatly when strategic sourcing is embraced to reduce costs, introduce sourcing management systems designed to address the organization's needs, and work with the organization to streamline sourcing management (Mwenda, 2012). 
Table 5: Strategic Sourcing

\begin{tabular}{|c|c|c|c|c|c|c|c|}
\hline Statements & $\begin{array}{c}\text { Strongl } \\
\mathbf{y} \\
\text { Disagr } \\
\text { ee } \\
\end{array}$ & $\begin{array}{c}\text { Disagr } \\
\text { ee }\end{array}$ & $\begin{array}{c}\text { Neutra } \\
1\end{array}$ & Agree & $\begin{array}{c}\text { Strongl } \\
\text { y } \\
\text { Agree } \\
\end{array}$ & $\begin{array}{c}\text { Mea } \\
\mathbf{n}\end{array}$ & $\begin{array}{c}\text { Std. } \\
\text { Deviati } \\
\text { on }\end{array}$ \\
\hline $\begin{array}{lll}\text { Outsourcing } & \text { plays } & \text { a } \\
\text { significant } & \text { role } & \text { in } \\
\text { profitability } & & \\
\text { improvement } & & \end{array}$ & $6.00 \%$ & $5.10 \%$ & $5.10 \%$ & $42.70 \%$ & $41.00 \%$ & 4.08 & 1.1 \\
\hline $\begin{array}{l}\text { Green } \quad \text { procurement } \\
\text { plays a significant role } \\
\text { in } \\
\text { improvement }\end{array}$ & $8.50 \%$ & $11.10 \%$ & $25.60 \%$ & $27.40 \%$ & $27.40 \%$ & 3.54 & 1.242 \\
\hline $\begin{array}{l}\text { Multi sourcing plays a } \\
\text { significant role in } \\
\text { profitability } \\
\text { improvement }\end{array}$ & $13.70 \%$ & $15.40 \%$ & $20.50 \%$ & $23.10 \%$ & $27.40 \%$ & 3.35 & 1.385 \\
\hline $\begin{array}{l}\text { Outsourcing plays a } \\
\text { significant role in } \\
\text { expanding market share }\end{array}$ & $4.30 \%$ & $7.70 \%$ & $1.70 \%$ & $45.30 \%$ & $41.00 \%$ & 4.11 & 1.057 \\
\hline $\begin{array}{l}\text { Green procurement } \\
\text { plays a significant role } \\
\text { in expanding market } \\
\text { share }\end{array}$ & $2.60 \%$ & $6.80 \%$ & $3.40 \%$ & $42.70 \%$ & $44.40 \%$ & 4.2 & 0.976 \\
\hline $\begin{array}{l}\text { Multi sourcing plays a } \\
\text { significant role in } \\
\text { expanding market share }\end{array}$ & $3.40 \%$ & $0.00 \%$ & $11.10 \%$ & $42.70 \%$ & $42.70 \%$ & 4.21 & 0.899 \\
\hline $\begin{array}{lcc}\text { Outsourcing } & \text { plays a } \\
\text { significant role in } \\
\text { attaining } & \text { higher } \\
\text { customer satisfaction }\end{array}$ & $0.00 \%$ & $2.60 \%$ & $15.40 \%$ & $35.00 \%$ & $47.00 \%$ & 4.26 & 0.814 \\
\hline $\begin{array}{l}\text { Green procurement } \\
\text { plays a significant role } \\
\text { in attaining higher } \\
\text { customer satisfaction }\end{array}$ & $11.10 \%$ & $3.40 \%$ & $5.10 \%$ & $32.50 \%$ & $47.90 \%$ & 4.03 & 1.296 \\
\hline $\begin{array}{l}\text { Multi sourcing plays a } \\
\text { significant role in } \\
\text { attaining higher } \\
\text { customer satisfaction }\end{array}$ & $5.10 \%$ & $3.40 \%$ & $5.10 \%$ & $51.30 \%$ & $35.00 \%$ & 4.08 & 1.001 \\
\hline Average & & & & & & 3.98 & 1.085 \\
\hline
\end{tabular}




\subsection{Correlation Analysis}

Correlation analysis was used to determine both the significance and degree of association of the variables and also predict the level of variation in the dependent variable caused by the explanatory variables. The correlation technique is used to analyze the degree of relationship between two variables. The results of the correlation analysis are summarized in Table 6 .

Table 6: Summary of Pearson's Correlations

\begin{tabular}{|c|c|c|c|c|c|c|}
\hline & & $\begin{array}{l}\text { Supply } \\
\text { Base } \\
\text { Leveraging } \\
\end{array}$ & $\begin{array}{l}\text { Inventory } \\
\text { Managem } \\
\text { ent System }\end{array}$ & $\begin{array}{c}\text { E- } \\
\text { procure } \\
\text { ment }\end{array}$ & $\begin{array}{l}\text { Strategic } \\
\text { Sourcing } \\
\end{array}$ & $\begin{array}{c}\text { Perform } \\
\text { ance } \\
\text { State } \\
\text { Corporat } \\
\text { ions } \\
\end{array}$ \\
\hline $\begin{array}{l}\text { Supply Base } \\
\text { Leveraging }\end{array}$ & $\begin{array}{l}\text { Pearson } \\
\text { Correlation } \\
\text { Sig. (2-tailed) }\end{array}$ & 1 & & & & \\
\hline $\begin{array}{l}\text { Inventory } \\
\text { Management } \\
\text { System }\end{array}$ & $\begin{array}{l}\text { Pearson } \\
\text { Correlation } \\
\text { Sig. (2-tailed) }\end{array}$ & $\begin{array}{c}.746^{* *} \\
0\end{array}$ & 1 & & & \\
\hline $\begin{array}{l}\text { E- } \\
\text { procurement }\end{array}$ & $\begin{array}{l}\text { Pearson } \\
\text { Correlation } \\
\text { Sig. (2-tailed) }\end{array}$ & $\begin{array}{c}.703 * * \\
0\end{array}$ & $\begin{array}{c}.827 * * \\
0\end{array}$ & 1 & & \\
\hline $\begin{array}{l}\text { Strategic } \\
\text { Sourcing }\end{array}$ & $\begin{array}{l}\text { Pearson } \\
\text { Correlation } \\
\text { Sig. (2-tailed) }\end{array}$ & $\begin{array}{c}.665^{* *} \\
0\end{array}$ & $\begin{array}{c}.808 * * \\
0\end{array}$ & $\begin{array}{c}.927 * * \\
0\end{array}$ & 1 & \\
\hline $\begin{array}{l}\text { Performance } \\
\text { of } \quad \text { State } \\
\text { Corporation } \\
s\end{array}$ & $\begin{array}{l}\text { Pearson } \\
\text { Correlation } \\
\text { Sig. (2-tailed) }\end{array}$ & $\begin{array}{l}.740 * * \\
0.000\end{array}$ & $\begin{array}{l}.909 * * \\
0.000\end{array}$ & $\begin{array}{l}.828^{* *} \\
0.000\end{array}$ & $\begin{array}{l}.837 * * \\
0.000\end{array}$ & 1 \\
\hline
\end{tabular}

** Correlation is significant at the 0.05 level (2-tailed).

The correlation summary shown in Table 4.10 indicates that the associations between each of the independent variables and the dependent variable were all significant at the $95 \%$ confidence level. The correlation analysis to determine the relationship between supply base leveraging on the performance of state corporations in Kenya, Pearson correlation coefficient computed and tested at 5\% significance level. The results indicate that there is a positive relationship $(\mathrm{r}=0.740)$ between supply base leveraging and performance of state corporations in Kenya. In addition, the researcher found the relationship to be statistically significant at $5 \%$ level $(\mathrm{p}=0.000,<0.05)$. 
The correlation analysis to determine the relationship between inventory management system and performance of state corporations in Kenya, Pearson correlation coefficient computed and tested at $5 \%$ significance level. The results indicate that there is a positive relationship $(\mathrm{r}=0.909)$ between inventory management system and performance of state corporations in Kenya. In addition, the researcher found the relationship to be statistically significant at 5\% level $(\mathrm{p}=0.000,<0.05)$.

The correlation analysis to determine the relationship between E-procurement and performance of state corporations in Kenya, Pearson correlation coefficient computed and tested at $5 \%$ significance level. The results indicate that there is a positive relationship ( $\mathrm{r}=0$. 828 ) inventory E-procurement and performance of state corporations in Kenya. In addition, the researcher found the relationship to be statistically significant at $5 \%$ level $(\mathrm{p}=0.000$, $<0.05)$.

The correlation analysis to determine the relationship between strategic sourcing and performance of state corporations in Kenya, Pearson correlation coefficient computed and tested at 5\% significance level. The results indicate that there is a positive relationship $(\mathrm{r}=0.837)$ between strategic sourcing and performance of state corporations in Kenya. In addition, the researcher found the relationship to be statistically significant at $5 \%$ level $(\mathrm{p}=0.000,<0.05)$.

\subsection{Regression Analysis}

In this study multivariate regression analysis was used to determine the significance of the relationship between the dependent variable and all the independent variables pooled together. Regression analysis was conducted to find the proportion in the dependent variable (performance of state corporations in Kenya) which can be predicted from the independent variables (supply base leveraging, inventory management system, E-procurement and strategic sourcing).

Table 7 presents the regression coefficient of independent variables against dependent variable. The results of regression analysis revealed there is a significant positive relationship between dependent variable and the independent variable. The independent variables reported $\mathrm{R}$ value of 0.928 indicating that there is perfect relationship between dependent variable and independent variables. $\mathrm{R}$ square value of 0.861 means that $86.1 \%$ of the corresponding variation in performance of state corporations in Kenya can be explained or predicted by; (supply base leveraging, inventory management system, e-procurement and strategic sourcing).

The adjusted $\mathrm{R}$ square in the table 0.856 is called the coefficient of determination which indicates how performance of state corporations in Kenya varied with variation in effects of factors which includes; supply base leveraging, inventory management system, Eprocurement and strategic sourcing. The results of regression analysis revealed that there was a significant positive relationship between dependent variable and independent variable at $(\beta$ $=0.1108), \mathrm{p}=0.000<0.05)$. 
Table 7: Model Summary

\begin{tabular}{lllll}
\hline Model & R & R Square & Adjusted R Square & $\begin{array}{l}\text { Std. Error of the } \\
\text { Estimate }\end{array}$ \\
\hline 1 & $.928 \mathrm{a}$ & .861 & .856 & .1108 \\
\hline
\end{tabular}

a) Predictors: (Constant), , Supply Base Leveraging, Inventory Management System, Eprocurement and Strategic Sourcing

b) Dependent Variable: Performance of State Corporations

The research used a multiple regression model

$Y=\beta_{0}+\beta_{1} X_{1}+\beta_{2} X_{2}+\beta_{3} X_{3}+\beta_{4} X_{4}+\mathcal{E}$

Where $\mathbf{Y}=$ Performance of State Corporations

$\boldsymbol{\beta}_{0}=$ Constant

$\mathbf{X}_{\mathbf{1}}=$ Supply Base Leveraging

$\mathbf{X}_{\mathbf{2}}=$ Inventory Management System

$\mathbf{X}_{\mathbf{3}}=$ E-procurement

$\mathbf{X}_{4}=$ Strategic Sourcing

$\boldsymbol{\varepsilon}=$ Error Term at $95 \%$ confidence level.

The regression equation will be;

$Y=0.567+0.11 X_{1}+0.561 X_{2}+0.019 X_{3}+0.198 X_{4}$

The regression equation above has established that taking all factors into account (supply base leveraging, inventory management system, E-procurement and strategic sourcing) constant at zero, performance of State Corporations in Kenya will be an index of 0.567. The findings presented also shows that taking all other independent variables at constant, a unit increase in supply base leveraging will lead to a 0.11 increase in performance of state corporations in Kenya. The P-value was 0.02 which is less 0.05 and thus the relationship was significant.

The study also found that a unit increase in inventory management system will lead to a 0.561 increase in performance of state corporations in Kenya. The P-value was 0.00 and thus the relationship was significant. In addition, the study found that a unit increase in Eprocurement will lead to a 0.019 increase in the performance of state corporations in Kenya. The P-value was 0.01 and thus the relationship was significant.

Lastly, the study found that a unit increase in strategic sourcing will lead to a 0.198 increase in the performance of state corporations in Kenya. The P-value was 0.00 and hence the 
relationship was significant since the p-value was lower than 0.05 . The findings of the study show that, inventory management system contributed most to the performance of state corporations in Kenya.

Table 8: Coefficients of Determination

\begin{tabular}{|c|c|c|c|c|c|c|}
\hline \multirow[t]{2}{*}{ Model } & & \multicolumn{2}{|c|}{$\begin{array}{l}\text { Unstandardized } \\
\text { Coefficients }\end{array}$} & \multirow{2}{*}{$\begin{array}{l}\text { Standardized } \\
\text { Coefficients } \\
\text { Beta }\end{array}$} & \multirow[t]{2}{*}{$\mathrm{t}$} & \multirow[t]{2}{*}{ Sig. } \\
\hline & & B & Std. Error & & & \\
\hline \multirow[t]{5}{*}{1} & (Constant) & 0.567 & 0.199 & & 2.849 & .000 \\
\hline & $\begin{array}{l}\text { Inventory } \\
\text { Management } \\
\text { System }\end{array}$ & .561 & 0.064 & 0.617 & 8.807 & .000 \\
\hline & $\begin{array}{l}\text { Strategic } \\
\text { Sourcing }\end{array}$ & .198 & 0.063 & 0.304 & 3.168 & .000 \\
\hline & $\begin{array}{l}\text { Supply } \\
\text { Leveraging }\end{array}$ & .112 & 0.058 & 0.104 & 1.906 & .02 \\
\hline & E-procurement & .019 & 0.053 & 0.037 & 0.36 & .01 \\
\hline
\end{tabular}

Table 9: ANOVA

\begin{tabular}{rlrrrrr}
\hline \multirow{2}{*}{ Model } & & $\begin{array}{c}\text { Sum of } \\
\text { Squares }\end{array}$ & df & Mean Square & F & Sig. \\
& & 8.551 & 4 & 2.138 & 173.899 & $.000^{\mathrm{b}}$ \\
\multirow{2}{*}{1} & Regression & 1.377 & 112 & 0.012 & & \\
& Residual & 9.927 & 116 & & & \\
& Total & & & & & \\
& & & & & & \\
\end{tabular}
a) Predictors: (Constant), , Supply Base Leveraging, Inventory Management System, E- procurement and Strategic Sourcing
b) Dependent Variable: Performance of State Corporations

The significance value is 0.000 which is less that 0.05 thus the model is statistically significant in predicting how supply base leveraging, inventory management system, eprocurement and strategic sourcing influence performance of state corporations in Kenya. The F critical at 5\% level of significance was 16.8. Since F calculated which can be noted from the ANOVA table above is 35.546 which is greater than the F critical (value $=16.80$ ), this shows that the overall model was significant. The study therefore establishes that; supply base leveraging, inventory management system, e-procurement and strategic sourcing, were all important practices influencing performance of state corporations. These results agree 
with Amaratunga (2012) results which indicated a positive and significant influence of strategic procurement management on performance of state corporations.

\subsection{DISCUSSIONS, CONCLUSIONS AND RECOMMENDATIONS}

\subsection{Discussions}

\subsubsection{Supply Base Leveraging}

The study sought to assess influence of supply base leveraging on performance of state corporations as the first objective of the study. A majority of respondents were found to highly agree that the state corporations had embraced supply base leveraging with regard to its procurement activities. Strategic alliances and supplier optimization were common in the state corporations. Correlation and regression results revealed that this was an important variable that could perhaps be explained by the observation from the findings that supply base leveraging was an important factor in influencing performance of state corporations.

\subsubsection{Inventory Management System}

The influence of inventory management system on performance of state corporations was the second objective of the study. A majority of respondents were found to highly agree that the state corporations had embraced inventory management system with regard to its procurement activities. Just in time and vendor managed inventory were common in the state corporations. Correlation and regression results revealed that this was an important variable that could perhaps be explained by the observation from the findings that inventory management system was an important factor in influencing performance of state corporations.

\subsubsection{E-Procurement}

The study endeared to assess influence of e-procurement on performance of state corporations as the third objective of the study. A majority of respondents were found to highly agree that the state corporations had embraced e-procurement with regard to its procurement activities. Electronic sourcing and electronic payments were common in the state corporations. Correlation and regression results revealed that this was an important variable that could perhaps be explained by the observation from the findings that eprocurement was an important factor in influencing performance of state corporations.

\subsubsection{Strategic Sourcing}

The study sought to assess influence of strategic sourcing on performance of state corporations as the last objective of the study. A majority of respondents were found to highly agree that the state corporations had embraced strategic sourcing with regard to its procurement activities. Outsourcing and green procurement were common in the state corporations. Correlation and regression results revealed that this was an important variable that could perhaps be explained by the observation from the findings that strategic sourcing was an important factor in influencing performance of state corporations.

\subsubsection{Performance of State Corporations}

The study endeared to determine influence of strategic procurement management on performance with reference to state corporations. The regression results revealed that strategic procurement strategies identified in the study, that is, supply base leveraging, inventory management system, e-procurement and strategic sourcing combined could explain 
approximately $86.1 \%$ of the variations in the performance of state corporations. The other $13.9 \%$ may be attributed to other strategies not explained by the model or the variables.

Quality of goods purchased recorded positive growth, timely purchases and stock out reduction further recorded positive growth, cost reductions due to minimal or no reworks also recorded positive growth. From inferential statistics, a positive correlation is seen between each predictor variable and performance of the state corporations. The strongest correlation was established between inventory management system and performance of the state corporations. All the independent variables were found to have a statistically significant association with the dependent variable at ninety five percent level of confidence.

\subsection{Conclusion}

Based on the study findings, the study concludes that performance of state corporations can be improved by supply base leveraging, inventory management system, e-procurement and strategic sourcing.

First, in regard to inventory management system, the regression coefficients of the study show that it has a significant influence of 0.561 on performance of state corporations. This implies that increasing levels of inventory management system by a unit would increase the levels of performance of the state corporations by 0.561. This shows that inventory management system has a positive influence on performance of state corporations.

Second in regard to strategic sourcing, the regression coefficients of the study show that it has a significant influence of 0.198 on performance of state corporations. This implies that increasing levels of strategic sourcing by a unit would increase the levels of performance of the state corporations by 0.198 . This shows that strategic sourcing has a positive influence on performance of state corporations.

With regard to supply base leveraging, the regression coefficients of the study show that it has a significant influence of 0.112 on performance of state corporations. This implies that increasing levels of supply base leveraging by a unit would increase the levels of performance of the state corporations by 0.112 . This shows that supply base leveraging has a positive influence on performance of state corporations.

Lastly, in regard to the fourth objective, the regression coefficients of the study show that it has a significant influence of 0.019 on performance of state corporations. This implies that increasing levels of e-procurement by a unit would increase the levels of performance of the state corporations by 0.019 . This shows that e-procurement has a positive influence on performance of state corporations.

Drawing on this research, lack of supply base leveraging, inventory management system, eprocurement and strategic sourcing, in state corporations is leading to poor performance. Though the state corporations are striving hard to improve their performance there are still issues of poor quality products, long lead time and high cost of projects/products. It was articulated that the current phenomenon of poor performance in the public sector can be reversed if the government and other stakeholders ensure supply base leveraging, inventory management system, e-procurement and strategic sourcing are embraced in the procurement function. Thus, it is evident that all the independent variables identified in this study were all important strategic procurement management activities that influenced the performance of state corporations. 


\subsection{Recommendations of the Study}

To ensure that state corporations have better performance they should focus more on using their supply base leveraging so as to ascertain the realistic capability of vendors, their realistic technical capacity and ensure that there is consistency of quality in goods supplied.

With regard to the second objective, it would be constructive for state corporations to invest more in inventory management system to reduce the cost of stock management through unnecessary embezzlement and ensure professional suppliers get it right the first time. This should be done consistently with the partnerships, training and capacity building.

In relation to e-procurement, the organizations should form strategic technological alliances with their vendors so as to have a more improved working relationship characterized by electronic data interchange. If state corporations embrace systems integration among its suppliers then there will be cost reduction and timing of delivery will improve.

Concerning strategic sourcing, there is need for state corporations to always set aside a substantial part of their resources for activities that spend a huge amount of total resources, and this entails the sourcing management. This is because decisions made here have major effects on later stages. In the same regard, they should embrace continuous replenishment policy to enable them to come up with cost efficient strategies that articulate with their organization objectives.

The study recommends that procurement staff in the state corporations should ensure that they strictly follow procurement procedures to ensure that goods supplied are of the right quality, in the right quantity, at the right time, to the right place from the right source. This will aim at satisfaction of customers in terms of cost, quality, and timeliness of the delivered product or service, minimizing administrative operating costs, conducting business with integrity, fairness and openness. More checks and controls should be introduced to check on the integrity of the sourcing systems.

\subsection{Areas for Further Studies}

The study is a milestone for further research in the field of performance of state corporations in Africa and particularly in Kenya. The findings demonstrated the important strategic procurement issues to performance of state corporations to include; supply base leveraging, inventory management system, e-procurement and strategic sourcing. The current study should therefore be expanded further in future in order to include other strategic procurement strategies that may as well have a positive significance to performance of state corporations. Existing literature indicates that as a future avenue of research, there is need to undertake similar research in other institutions and public sector organizations in Kenya and other countries in order to establish whether the explored strategic procurement management herein can be generalized to affect performance in other public institutions. 


\section{REFERENCES}

Andersen, T. (2010). "Integrating the strategy formation process: An international perspective", European Management Journal, 22(3), 263-272

Central Bank of Kenya (2013). Status of the Manufacturing Sector in Kenya. Nairobi: Government Press.

Chandler, A. D. (2012). Strategy and Structure. Cambridge, MA: MIT Press.

Cox, A. (2013). "The art of the possible: relationship management in power regimes and supply chains", Supply Chain Management: An International Journal.

Cummings, G., \& Qiao, Y. (2013). "The use of qualification-based selection in public procurement: a survey research", Journal of Public Procurement.

Gabbard, E.G. (2014). Strategic Sourcing: Critical Elements and Keys to Success, Paper presented at Institute of Supply Management International Conference, Tempe, Arizona, April 2014.

Humphreys, P., McIvor, R., \& Cadden, T. (2010). "B2B commerce and its implications for the buyer-supplier interface", Supply Chain Management: An International Journal.

Johnson, G., Scholes, K., \& Whittington, R. (2010). Exploring corporate strategy. Harlow: Financial Times Prentice Hall.

KIPPRA (2010). The Demographic Governance Support Programme (DGSP). Nairobi: KIPPRA.

Knudsen, D. (2009). Improving procurement performance with E-business mechanisms. Lund University. Lund, Sweden.

Kotabe, M., \& Murray, J.Y. (2010). “'Outsourcing, performance, and the role of e-commerce: a dynamic perspective', Industrial Journal of Marketing and Management, 3(7), 3745

Lysons, K. (2013). Purchasing and supply chain management 7th Edition. New York: McGraw-Hall.

Ming-Ling, C., Shaw, W. (2012). A Roadmap for E-Business Implementation. Engineering Management Journal, 17(2), 3-13

Mose, P.N. (2012). An Assessment of the Extent Of Compliance With Public Procurement And Disposal Act 2005 In Level 5 Hospitals In Kenya: A Study Of Kisii Level 5 Hospital. Unpublished MBA Report, Egerton University, Kenya

Mugenda, O. \& Mugenda, A. (2014). Research methods quantitative and qualitative approaches. Nairobi: Acts Press. 
Mwenda, M.M. (2012). Application of business process outsourcing strategy in small and medium food manufacturing firms in Kenya: University of Nairobi, Nairobi, Kenya.

Nderu, M. (2013). Influence of Survival Strategies on the Organizational Performance of Kenya Airways, International Journal of Social Sciences and Entrepreneurship, 1(2), 496-512

Noor I., Guyo, W. \& Amuhaya, I. (2013). "Factors Affecting Implementation of EProcurement Practices in Public Service in Kenya", International Journal of Science and Research

Nyariki, N. R. (2013). Strategic management practices as a competitive tool in enhancing the performance of small and medium enterprises in Kenya. University of Nairobi

Nzuve, S. \& Musyoka, A. (2012). Human Capital Management Practices Adopted by the National Social Security Fund, Research Journal of Multidisciplinary Social Sciences, Nairobi, Kenya

Odundo, E.O. (2012). Environmental context, implementation of strategic plans and performance of State Corporations in Kenya. Digital Repository, University of Nairobi

PPOA. (2010). Assessing Procurement Systems in Kenya Report. Nairobi: Public Oversight Authority.

Qiu, J. H. (2012). The Executive Leadership and Performance Management: Showwe.

Rotich, L. M. (2011). Influence of Planning on Procurement Performance in the Kenya, International Journal of Human Resource and Research Publication, 1(2), 289-292

Sari, K. (2012).'Inventory in Accuracy and Performance of Collaborative Supply Chain Practices”, Journal of Industrial Management and Data Systems, 2(4), 108-123

Strickland, T. (2009). Strategic Management, concepts and Cases, 10th Edition. Boston: Homewood.

Taiwo, S. \& Idumo, F. (2010). Impact of strategic Planning on Organizational Performance and Survival. Research Journal of Business Management 1(1), 62-71.

Thai, K.V. (2011). "Advancing public procurement: practices, innovation and knowledge sharing", Innovation and Knowledge-sharing, Academics Press, Boca Raton, FL.

Wangari, B. (2013). Influence of competitive strategies on the performance of hair salons in Nairobi. Unpublished MBA Project report, University of Nairobi

World Bank (2013). "Reducing Supply Chain Barriers Could Increase Global GDP Up To 6 Times More Than Removing All Import Tariffs Report", Switzerland 